\title{
EXTRACTION OF NATURAL DYE FROM DIOSPYROS MOLLIS (GRIFF.) FRUITS BY MANY DIFFERENT SOLVENTS AND APPLICATION OF DYED ON SILK FABRIC
}

\author{
PHAM THI HONG PHUONG ${ }^{1}$, LE VO SON QUAN ${ }^{2}$, LE THI KIM PHUNG ${ }^{2}$, \\ HOANG THI LINH ${ }^{3}$, TRAN TRUNG KIEN ${ }^{4}$ \\ ${ }^{I}$ Faculty Of Chemical Engineering, Industrial University of Ho Chi Minh City; \\ ${ }^{2}$ Faculty Of Chemical Engineering, Ho Chi Minh City University of Technology; \\ ${ }^{3}$ School Of Chemical Engineering, Hanoi University of Science and Technology; \\ phamthihongphuong@iuh.edu.vn
}

\begin{abstract}
Diospyros mollis (Griff.) locally known as "mac nua", is a kind of wild plant which fruits are used to dye the famous black "Lanh My A" silk of Tan Chau, An Giang. In this study, the author uses four solvents: water, ethanol, acetone and diethyl ether to extract natural dye and it's used dyeing for silk. As a result, the natural dye extracted with acetone solution from Diospyros mollis (Griff.) fruits was used to dye for silk that obtained a color saturation 3.72 which was the best solvent. Silk fabric after dyeing has achieved the level of 4-5 color fastness, high mechanical strength and the ecological properties.
\end{abstract}

Key words. Diospyros mollis (Griff.), Silk fabric, Natural dye

\section{INTRODUCTION}

Form and development from needs of human, the textile dyeing has brought in a variety of species and colors; but the awareness of environment as well as increasing disputes about the risks of synthetic dyes resulted in growing interest in natural resources, environmentally friendly products and new strategies. Natural dyes and pigments have been used rigorously for millennia, up to the middle of the 19th century. The invention of the first synthetic dyes changed the situation and were substituted for natural colorants almost completely. However, in some niche segments or specialty segments of the market natural dyes survived. Diospyros Mollis Griff is a shrub growing in South-East Asian countries and bears the fruits of $2 \div 2.5 \mathrm{~cm}$ in diameter in summer. The extracts of the fresh fruits are used in Vietnam as a natural black dye in textile applications and a readily oxidizable phenolic constituent, named Diospyrol. Diospyrol is very sensitive to air and turn black. Besides, the process of the formation of black pigment is assumed to be rather complicated including polymerization due to phenol radical coupling, quinone-phenol rearrangement, and formation of charge-transfer complex between phenols and quinons, etc...Therefore, Diospyros Mollis Griff can be used for dyeing textile materials [4,5].

\section{MATERIALS AND METHODOLOGY}

\subsection{Materials}

Diospyros Mollis were picked from the parks in Ho Chi Minh City. Silk fabrics have sourced from Nha Xa, Moc Nam, Duy Tien, Ha Nam Province (fiber number 40/1 and density of $50 \mathrm{gram} / \mathrm{m}^{2}$, brightness $L^{*}$ 88.65). Solvents were used such as diethyl ether, acetone, ethanol and distilled water. Three solvents (diethyl ether, acetone and ethanol) were purchased from Xilong Chemical, China.

\subsection{Methodology}

\subsubsection{Determination of solvent extraction}

Green Diospyros Mollis fruits are collected stored in the

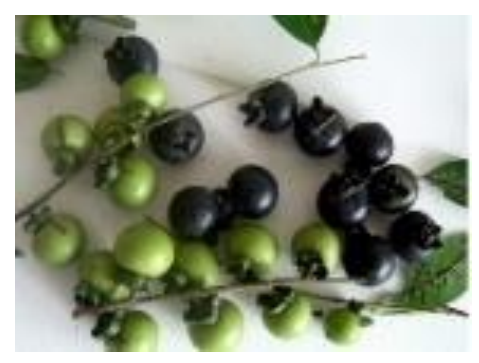

Figure 1. Diospyros Mollis Griff

refrigerator from 5 to 7 days. The natural colour solution was extracted from Diospyros Mollis fruits in different solvents. The ratio of Diospyros Mollis fruits/solvents is 1/5. Extracting temperature was observed in 1 hour at $30^{\circ} \mathrm{C}$ (room temperature), $34^{\circ} \mathrm{C}$ (boiling temperature of diethyl ether), $78^{\circ} \mathrm{C}$ (boiling temperature of ethanol), $56^{\circ} \mathrm{C}$ (boiling temperature of acetone) and $100^{\circ} \mathrm{C}$ (boiling temperature of water). 


\subsubsection{Experimental determination of extraction conditions}

Selected suitable extracting solvent was carried out to survey the factors affect to extraction process such as: extracting temperature from $30^{\circ} \mathrm{C}$ to $56^{\circ} \mathrm{C}$; extracting time from 45 to $90 \mathrm{~min}$, extracting rate Diospyros Mollis fruits/ solvents (Material/Liquid) from 1/2 to 1/6. The natural colour solution was measured optical density (D) by UV-VIS methods. The exhaustion of natural colour solution on silk fabric $(\alpha)$ is determined by formula:

$$
\alpha=\frac{D_{1}-D_{2}}{D_{1}} \times 100 \%
$$

\subsubsection{Dyeing}

Dyeing silk fabric: The natural colour aqueous was extracted from Diospyros Mollis fruits in different solvents, selected suitable extracting solvent and used dyeing for silk fabrics with the ratio of silk fabric/water $1 / 20$; dyeing temperature $60^{\circ} \mathrm{C}$, dyeing time $30 \mathrm{~min}$.

Determining color intensity $\left(C^{*}\right)$ : The results of study were evaluated by determining color intensity $\left(\mathrm{C}^{*}\right)$ and color fastness of dyed silk fabric with $\mathrm{L}^{*}, \mathrm{a}^{*}, \mathrm{~b}^{*}$ in color CIELAB system by X-Rite model SP60 colorimeter machine, Japan [3].

$$
C^{*}=\sqrt{\left(a^{*}\right)^{2}+\left(b^{*}\right)^{2}}
$$

The color fastness of silk fabrics after dyeing were tested by the standard of washing (ISO 105- C01) for the highest fastness levels 5 and the lowest fastness levels 1 ; and the properties of aqueous extracts and dyed silk fabrics were evaluated by spectroscopic analysis methods such as FTIR, LC-MS and scanning electron microscope SEM.

\section{RESULTS AND DISCUSSION}

\subsection{Effect of the extracting solvents to the exhaustion of natural colour solution on silk fabric and the color intensity of dyed silk fabric}

The result of investigate the change of optical density (D) and the exhaustion of natural colour solution on silk fabric $(\alpha)$ arcording to the extracting solvents (water, ethanol, diethyl ether and acetone) is showed in table 1,2 .

Table 1. The result of the extracting solvents to optical density (D) and the exhaustion of natural colour solution on

\begin{tabular}{|c|c|c|c|c|c|c|c|c|}
\hline \multirow[t]{2}{*}{$\mathrm{N}_{0}$} & \multicolumn{2}{|c|}{ Water } & \multicolumn{2}{|c|}{ Ethanol } & \multicolumn{2}{|c|}{ Acetone } & \multicolumn{2}{|c|}{ Diethyl Ether } \\
\hline & D1 & D2 & D1 & D2 & D1 & D2 & D1 & D2 \\
\hline & \multicolumn{8}{|c|}{$\mathrm{t}=30^{\circ}$} \\
\hline Optical Density & 2.388 & 1.682 & 2.219 & 1.507 & 3.371 & 1.853 & 0.043 & 0.609 \\
\hline $\begin{array}{l}\text { The exhaustion of natural } \\
\text { colour solution on silk fabric } \\
(\alpha) \%\end{array}$ & \multicolumn{2}{|c|}{29.564} & \multicolumn{2}{|c|}{32.087} & \multicolumn{2}{|c|}{45.031} & \multicolumn{2}{|c|}{-1316.279} \\
\hline & \multicolumn{2}{|c|}{$\mathrm{T}=100^{\circ}$} & \multicolumn{2}{|c|}{$\mathrm{T}=78^{\circ}$} & \multicolumn{2}{|c|}{$\mathrm{T}=56^{\circ}$} & \multicolumn{2}{|c|}{$\mathrm{T}=34^{\circ}$} \\
\hline Optical Density & 0.506 & 0.868 & 2.344 & 2.206 & 3.508 & 0.788 & 0.165 & 0.381 \\
\hline $\begin{array}{l}\text { The exhaustion of natural } \\
\text { colour solution on silk fabric } \\
(\alpha) \%\end{array}$ & \multicolumn{2}{|c|}{-71.542} & \multicolumn{2}{|c|}{5.887} & \multicolumn{2}{|c|}{77.537} & \multicolumn{2}{|c|}{-130.909} \\
\hline
\end{tabular}
silk fabric $(\alpha)$

The result of table 1, 2 and figure 2 shows the exhaustion of natural colour solution on silk fabric and color intensity of silk fabric after dyeing with the solution of natural colour that was extracted by acetone solvent were obtaied at maximum value $\alpha=77.537 \%$ and $C^{*}=5.122$. Besides, extracting temperature of 
acetone solvent is $56^{\circ} \mathrm{C}$; this solvent can perform easily that could not need complex device and can avoid decomposition of natural pigments. Therefore, acetone was selected to extract natural color from Diospyros Mollis fruits.

Table 2. The result of the extracting solvents to color intensity $\left(\mathrm{C}^{*}\right)$ on silk fabric after dyeing

\begin{tabular}{|l|c|c|c|c|}
\hline & $\mathrm{L}^{*}$ & $\mathrm{a}^{*}$ & $\mathrm{~b}^{*}$ & $\mathrm{C}^{*}$ \\
\hline Water $\left(\mathrm{T}=30^{\circ}\right)$ & 92.22 & -0.21 & 5.18 & 5.184 \\
\hline Ethanol $\left(\mathrm{T}=30^{\circ}\right)$ & 96.15 & -0.03 & 5.77 & 5.770 \\
\hline Acetone $\left(\mathrm{T}=30^{\circ}\right)$ & 94.75 & -0.02 & 5.85 & 5.850 \\
\hline Diethyl ether $\left(\mathrm{T}=30^{\circ}\right)$ & 98.21 & -0.48 & 4.21 & 4.237 \\
\hline Water $\left(\mathrm{T}=100^{\circ}\right)$ & 104.2 & -0.95 & 3.10 & 3.242 \\
\hline Ethanol $\left(\mathrm{T}=78^{\circ}\right)$ & 97.00 & -0.41 & 4.03 & 4.051 \\
\hline Acetone $\left(\mathrm{T}=56^{\circ}\right)$ & 95.78 & -0.15 & 5.12 & 5.122 \\
\hline Diethyl ether $\left(\mathrm{T}=34^{\circ}\right)$ & 99.98 & -0.64 & 3.70 & 3.755 \\
\hline White Sample & 105.8 & -1.4 & 3.5 & 3.770 \\
\hline
\end{tabular}

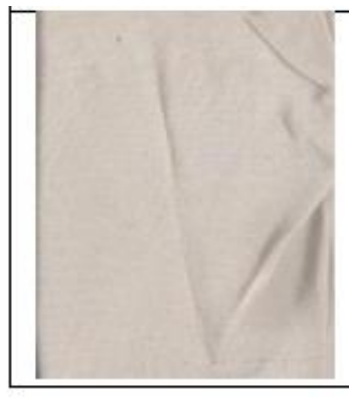

(a)

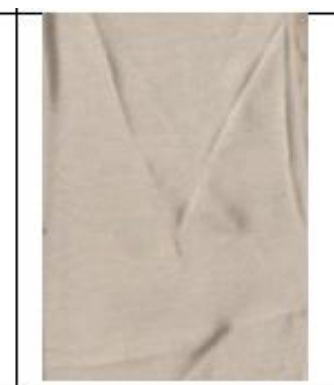

(b)

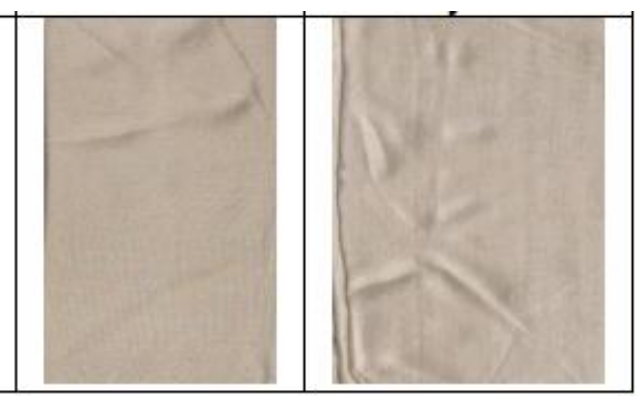

(c) (d)

Figure 2. The color of silk after dyeing in the solution of Diospyros Mollis fruits with Water (a), Ethanol (b), Acetone (c), Diethyl Ether (d)

3.2. Effect of technical factors of the extracting process to the exhaustion of natural color solution on silk fabric and the color intensity of dyed silk fabric

\subsubsection{Effect of the extracting temperature}

Table 3 . The result of the extracting temperature to color intensity $\left(\mathrm{C}^{*}\right)$ on silk fabric after dyei

\begin{tabular}{|c|c|c|c|c|c|c|c|c|c|}
\hline \multirow{2}{*}{$\begin{array}{l}\text { Time } \\
(\min )\end{array}$} & \multirow{2}{*}{$\begin{array}{l}\text { The ratio of } \\
\text { Diospyros } \\
\text { Mollis } \\
\text { fruits/ } \\
\text { solvents }\end{array}$} & \multirow{2}{*}{$\begin{array}{l}\text { Temperature } \\
\left({ }^{\circ} \mathrm{C}\right)\end{array}$} & \multicolumn{2}{|c|}{$\begin{array}{l}\text { Optical } \\
\text { Density }\end{array}$} & \multirow{2}{*}{$\begin{array}{c}\text { The } \\
\text { exhaustion } \\
\text { of natural } \\
\text { colour } \\
\text { aqueous } \\
\text { on silk } \\
\text { fabric }(\alpha)\end{array}$} & \multirow[b]{2}{*}{$\mathrm{L}^{*}$} & \multirow[b]{2}{*}{$a^{*}$} & \multirow[b]{2}{*}{$\mathrm{b}^{*}$} & \multirow{2}{*}{$\begin{array}{c}\text { Color } \\
\text { intensity } \\
\left(C^{*}\right)\end{array}$} \\
\hline & & & D1 & D2 & & & & & \\
\hline \multirow{4}{*}{60} & \multirow{4}{*}{$1 / 5$} & 30 & 3.316 & 2.455 & 25.97 & 81.23 & -0.47 & 5.65 & 5.67 \\
\hline & & 40 & 2.365 & 2.100 & 11.21 & 87.82 & -0.53 & 3.43 & 3.47 \\
\hline & & 50 & 3.316 & 2.100 & 36.67 & 84.64 & -0.51 & 4.14 & 4.17 \\
\hline & & 56 & 3.316 & 2.882 & 13.09 & 84.72 & -0.47 & 4.31 & 4.34 \\
\hline
\end{tabular}


The extracting time (60 min) and the ratio of Diospyros Mollis fruits/solvents (1/5) were constants during carried out this study; the extracting temperature from $30^{\circ} \mathrm{C}$ to $56^{\circ} \mathrm{C}$. Then the natural colour solution from Diospyros Mollis fruits was dyed for silk fabric. The result of the investigate is showed table 3 . The extracting temperature was effect to the dissolution of compounds in Diospyros Mollis fruits, the color intensity $\left(\mathrm{C}^{*}\right)$ decrease from 5.67 to 3.47 when the extracting temperature increase from 30 to $40{ }^{\circ} \mathrm{C}$ and was obtained the lowest value $\mathrm{C}^{*}=3.47$ at $40^{\circ} \mathrm{C}$.

\subsubsection{Effect of the extracting time}

The extracting temperature $\left(30^{\circ} \mathrm{C}\right)$ and the rate of Diospyros Mollis fruits/solvents (1/5) were constants during carried out this study; the extracting time from 45 to $90 \mathrm{~min}$. Then the natural colour solution from Diospyros Mollis fruits was dyed on silk fabric. The result of the study is showed table 4.

Table 4 . The result of the extracting time to color intensity $\left(\mathrm{C}^{*}\right)$ on silk fabric dyed

\begin{tabular}{|c|c|c|c|c|c|c|c|c|c|}
\hline \multirow{2}{*}{$\begin{array}{c}\text { Temperature } \\
\left({ }^{\circ} \mathrm{C}\right)\end{array}$} & \multirow{2}{*}{$\begin{array}{l}\text { The ratio } \\
\text { of } \\
\text { Diospyros } \\
\text { Mollis } \\
\text { fruits/ } \\
\text { solvents }\end{array}$} & \multirow{2}{*}{$\begin{array}{l}\text { Time } \\
(\min )\end{array}$} & \multicolumn{2}{|c|}{$\begin{array}{l}\text { Optical } \\
\text { Density }\end{array}$} & \multirow{2}{*}{$\begin{array}{c}\text { The } \\
\text { exhaustion } \\
\text { of natural } \\
\text { colour } \\
\text { aqueous on } \\
\text { silk fabric } \\
(\alpha)\end{array}$} & \multirow[b]{2}{*}{$\mathrm{L}^{*}$} & \multirow[b]{2}{*}{$a^{*}$} & \multirow[b]{2}{*}{$b^{*}$} & \multirow{2}{*}{$\begin{array}{c}\text { Color } \\
\text { intensity } \\
\left(C^{*}\right)\end{array}$} \\
\hline & & & D1 & D2 & & & & & \\
\hline \multirow{6}{*}{30} & \multirow{6}{*}{$1 / 5$} & 45 & 3.303 & 1.628 & 50.71 & 86.75 & -0.26 & 4.16 & 4.17 \\
\hline & & 50 & 3.303 & 1.917 & 41.96 & 85.39 & -0.14 & 4.44 & 4.44 \\
\hline & & 60 & 3.303 & 1.896 & 42.60 & 86.88 & -0.12 & 4.33 & 4.33 \\
\hline & & 70 & 3.303 & 2.607 & 21.07 & 86.20 & -0.09 & 4.57 & 4.57 \\
\hline & & 80 & 2.273 & 1.676 & 26.26 & 86.06 & -0.08 & 4.59 & 4.59 \\
\hline & & 90 & 3.303 & 2.145 & 35.06 & 85.52 & -0.12 & 4.75 & 4.75 \\
\hline
\end{tabular}

The result of the experiments is showed the extracting time incresae from 45 to $60 \mathrm{~min}$, the exhaustion of natural colour solution on silk fabric decrease from $50.71 \%$ to $42.60 \%$; and the color intensity $\left(\mathrm{C}^{*}\right)$ was effected no high from 4.17 to 4.33 . The extracting time best suitable is $60 \mathrm{~min}$ were obtained $\mathrm{C}^{*}=4.33$ and $\alpha=42.60 \%$ when is enough time for the compounds of Diospyros Mollis fruits to dissolve in acetone.

\subsubsection{Effect of the extracting ratio of Diospyros Mollis fruits/ solvents}

The extracting temperature at $30^{\circ} \mathrm{C}$ for 60 min were constants during carried out this study; the rate of Diospyros Mollis fruits/solvents is $1 / 2 \rightarrow 1 / 6$. Then the natural colour solution from Diospyros Mollis fruits was dyed for silk fabric. The result is showed in table 5.

Table 5. The result of ratio of Diospyros Mollis fruits/ solvents to color intensity $\left(\mathrm{C}^{*}\right)$ on silk fabric dyed

\begin{tabular}{|c|c|c|c|c|c|c|c|c|c|}
\hline \multirow[b]{2}{*}{$\begin{array}{c}\text { Temperature } \\
\left({ }^{\circ} \mathrm{C}\right)\end{array}$} & \multirow[b]{2}{*}{$\begin{array}{l}\text { Time } \\
\text { (min) }\end{array}$} & \multirow{2}{*}{$\begin{array}{l}\text { The ratio } \\
\text { of } \\
\text { Diospyros } \\
\text { Mollis } \\
\text { fruits/ } \\
\text { solvents }\end{array}$} & \multicolumn{2}{|c|}{$\begin{array}{l}\text { Optical } \\
\text { Density }\end{array}$} & \multirow{2}{*}{$\begin{array}{c}\text { The } \\
\text { exhaustion } \\
\text { of natural } \\
\text { colour } \\
\text { aqueous } \\
\text { on silk } \\
\text { fabric }(\alpha)\end{array}$} & \multirow[b]{2}{*}{$\mathrm{L}^{*}$} & \multirow[b]{2}{*}{$a^{*}$} & \multirow[b]{2}{*}{$\mathrm{b}^{*}$} & \multirow[b]{2}{*}{$\begin{array}{c}\text { Color } \\
\text { intensity } \\
\left(C^{*}\right)\end{array}$} \\
\hline & & & D1 & D2 & & & & & \\
\hline \multirow{5}{*}{30} & \multirow{5}{*}{60} & $1 / 2$ & 3.303 & 2.100 & 36.42 & 81.20 & -0.16 & 5.30 & 5.31 \\
\hline & & $1 / 3$ & 3.316 & 2.251 & 32.12 & 78.27 & -0.40 & 6.54 & 6.55 \\
\hline & & $1 / 4$ & 3.316 & 1.997 & 39.78 & 79.14 & -0.50 & 5.72 & 5.74 \\
\hline & & $1 / 5$ & 3.316 & 1.675 & 49.49 & 82.46 & -0.54 & 4.64 & 4.67 \\
\hline & & $1 / 6$ & 3.316 & 1.186 & 64.23 & 82.78 & -0.54 & 4.56 & 4.59 \\
\hline
\end{tabular}

The ratio of Diospyros Mollis fruits/ acetone is increase 1/2 to 1/5, the exhaustion of natural colour solution for silk fabric is also increase from $36.42 \%$ to $49.49 \%$ and the color intensity $\left(\mathrm{C}^{*}\right)$ decrease from 5.31 to 4.67. This can be explained that the most of amount of solvent dissolve the compounds of Diospyros Mollis 
fruits, the exhaustion of natural colour aqueous on silk fabric is also increase and obtained $\alpha=49.49$, $C^{*}=4.67$ with the ratio of Diospyros Mollis fruits/ acetone 1/5.

\subsection{Optimization of the extracting natural color process from Diospyros Mollis fruits by acetone solvent}

\subsubsection{The model experimental design of the extracting process by the model of orthogonal of level 2}

In order to build the mathematical model of the extracting natural color process form Diospyros Mollis fruits in acetone solvents, carried out experiment and obtain the result of by the model of orthogonal of level 1, then carried out experimental planning for the model of orthogonal of level 2 . Three variables were selected to this study $\mathrm{k}=3$, the number of experiments at orthogonal center are $2 \mathrm{k}=8$, the number of experiments carried out at center is $n_{0}=3$, number of experiments carried out at point $(*)$ are $2 k=6$. Thus, the sum of experiments have to carried out in the model of orthogonal of level 2 are $N=2 k+2 k+n_{0}=17$. Point $(*)$ is the point that distance from $(*)$ to real center has value are $\alpha$ and is calculated by formula (1):

$$
\alpha=\sqrt{\sqrt{N .2^{k-2}}-2^{k-1}}=\sqrt{\sqrt{17 \cdot 2^{3-2}}-2^{3-1}}=1.35
$$

In order to the matrix of experiments can orthogonal transfer the encode variables $X_{j}^{2}$ to the sub variables $X_{j}^{\prime}$ and is caculated by formular (2):

$$
X_{j}^{\prime}=X_{j}^{2}-\frac{2^{k}+2 \alpha^{2}}{N}=X_{j}^{2}-0.686
$$

The level of factors [basic level, upper level, lower level and level (*)] are shown in table 6:

Table 6. The level of factors of the model of orthogonal of level 2

\begin{tabular}{|l|c|c|c|}
\hline \multirow{2}{*}{ The level of factors } & \multicolumn{3}{|c|}{ The effects factors } \\
\cline { 2 - 4 } & Temperature $\left(\mathrm{Z}_{1}\right)$ & Time $\left(\mathrm{Z}_{2}\right)$ & Solid/liquid $\left(\mathrm{Z}_{3}\right)$ \\
\hline The encode variables & $\mathrm{X}_{1}$ & $\mathrm{X}_{2}$ & $\mathrm{X}_{3}$ \\
\hline Upper level $(+1)$ & 56 & 90 & 0.5 \\
\hline Basic level $(0)$ & 43 & 67.5 & 0.333 \\
\hline Lower level $(-1)$ & 30 & 45 & 0.167 \\
\hline The range of variables & 13 & 22.5 & 0.165 \\
\hline$\alpha$ & $+/-1.35$ & $+/-1.35$ & $+/-1.35$ \\
\hline
\end{tabular}

The value of objects function $Y_{1}$ is the maximum of the exhaustion of natural color solution on silk fabric and $\mathrm{Y}_{2}$ is the minimum of color intensity fabric are used to build for the regression equation level 2 by form below: $\hat{Y}=b_{0}+\sum_{j=1}^{3} b_{j} X_{j}+\sum_{j \neq 1}^{3} b_{i j} X_{j} X_{i}+\sum_{j=1}^{3} b_{j j} X_{j}^{2}$ (3)

The encode variables $\left(\mathrm{X}_{\mathrm{i}}\right)$ and the real variables $\left(\mathrm{Z}_{\mathrm{i}}\right)$ are collected to study at different levels are shown in the interactive equation:

$$
\boldsymbol{X}_{\boldsymbol{i}}=\frac{Z_{i}-Z_{i}^{0}}{\Delta \boldsymbol{Z}_{i}} ; \boldsymbol{Z}_{\boldsymbol{i}}=\left( \pm \propto \times \Delta_{\boldsymbol{i}}\right)+\boldsymbol{Z}_{\boldsymbol{i}}^{\mathbf{0}}
$$

$Z_{i}^{0}$ : The value of research at basic level $(0) ; \Delta_{\max }$ : The value of research at upper level $(+1)$; $\Delta_{\min }$ : The value of research at lower level (-1); $\Delta Z_{i}=\frac{Z_{\max }-Z_{\min }}{2}$ : The range of variables of research After encoding the variables and carried out experiments, the result of experiments in table 7.

Table 7. The matrix of experiments of the model of orthogonal of level 2

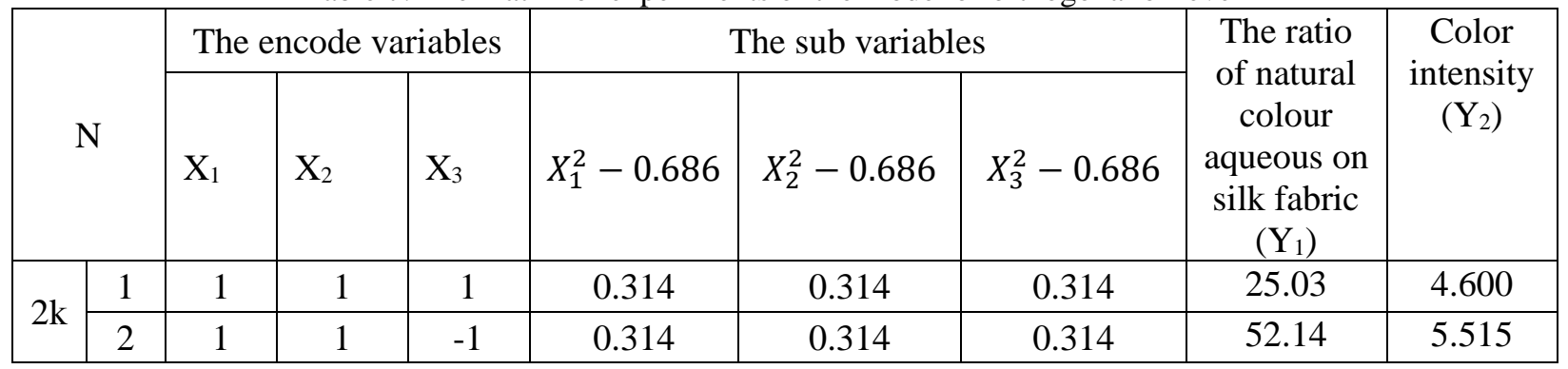




\begin{tabular}{|c|c|c|c|c|c|c|c|c|c|}
\hline & 3 & 1 & -1 & 1 & 0.314 & 0.314 & 0.314 & 63.09 & 4.018 \\
\hline & 4 & 1 & -1 & -1 & 0.314 & 0.314 & 0.314 & 64.23 & 4.855 \\
\hline & 5 & -1 & 1 & 1 & 0.314 & 0.314 & 0.314 & 40.95 & 4.425 \\
\hline & 6 & -1 & 1 & -1 & 0.314 & 0.314 & 0.314 & 68.31 & 5.421 \\
\hline & 7 & -1 & -1 & 1 & 0.314 & 0.314 & 0.314 & 50.81 & 3.639 \\
\hline & 8 & -1 & -1 & -1 & 0.314 & 0.314 & 0.314 & 3.34 & 3.739 \\
\hline \multirow{6}{*}{$2 \mathrm{k}$} & 9 & -1.35 & 0 & 0 & 1.1365 & -0.686 & -0.686 & 37.666 & 4.008 \\
\hline & 10 & 1.35 & 0 & 0 & 1.1365 & -0.686 & -0.686 & 35.525 & 3.483 \\
\hline & 11 & 0 & -1.35 & 0 & -0.686 & 1.1365 & -0.686 & 19.661 & 3.346 \\
\hline & 12 & 0 & 1.35 & 0 & -0.686 & 1.1365 & -0.686 & 36.671 & 3.721 \\
\hline & 13 & 0 & 0 & -1.35 & -0.686 & -0.686 & 1.1365 & 26.327 & 4.458 \\
\hline & 14 & 0 & 0 & 1.35 & -0.686 & -0.686 & 1.1365 & 42.099 & 3.088 \\
\hline \multirow{3}{*}{$\mathrm{n}_{0}$} & 15 & 0 & 0 & 0 & -0.686 & -0.686 & -0.686 & 16.671 & 3.436 \\
\hline & 16 & 0 & 0 & 0 & -0.686 & -0.686 & -0.686 & 15.29 & 3.273 \\
\hline & 17 & 0 & 0 & 0 & -0.686 & -0.686 & -0.686 & 19.662 & 3.350 \\
\hline
\end{tabular}

The data of experiments were solved by Statgraphics Centurion XV.II software to analyze correlation and regression, determine regression of the process, the coefficients of the regression equations and optimal for the regression function. And accreditation of the mathematical model. Checking the meaning of the coefficients according to the Student standard and the compatibility of the regression function compare with experiment. The result of the regression function by formula (4).

$$
\begin{gathered}
\widehat{Y_{1}}=17.074+1.34203 X_{1}+2.75716 X_{2}+2.45746 X_{3}+8.7707 X_{1}^{2}-6.045 X_{1} X_{2}- \\
12.6 X_{1} X_{3}+9.62159 X_{2}^{2}-13.1575 X_{2} X_{3}+6.61123 X_{3}^{2}(4)
\end{gathered}
$$

The extracting natural color process form Diospyros Mollis fruits in acetone solvents are shown by formula 4. This regression function are shown the influence of factors on the rate of natural colour aqueous on silk fabric and color intensity.

The influence of the extracting temperature: the extracting temperature have impact positive to the exhaustion of natural color solution on silk fabric and color intensity. In survey range, the ratio of natural color aqueous on silk fabric and color intensity decreases progressively and were obtained the minimum values at the center investigate; then these values increase progressively. This can be explained that extracting temperature support to solute the natural color from Diospyros Mollis fruits in acetone solvent and are obtained optimal value at $40^{\circ} \mathrm{C}$.

The influence of the extracting time: the ratio of natural color aqueous on silk fabric and color intensity decreases progressively at $60 \mathrm{~min}$, and time increase progressively is color intensity more increase. Thus, $60 \mathrm{~min}$ is enough time to dissolve the natural color from Diospyros Mollis fruits in acetone solvent.

The influence of the extracting ratio: the extracting ratio have impact positive and were obtained the minimum of rate of natural color aqueous on silk fabric and the color on dyed fabric the darkest color at 1/5.
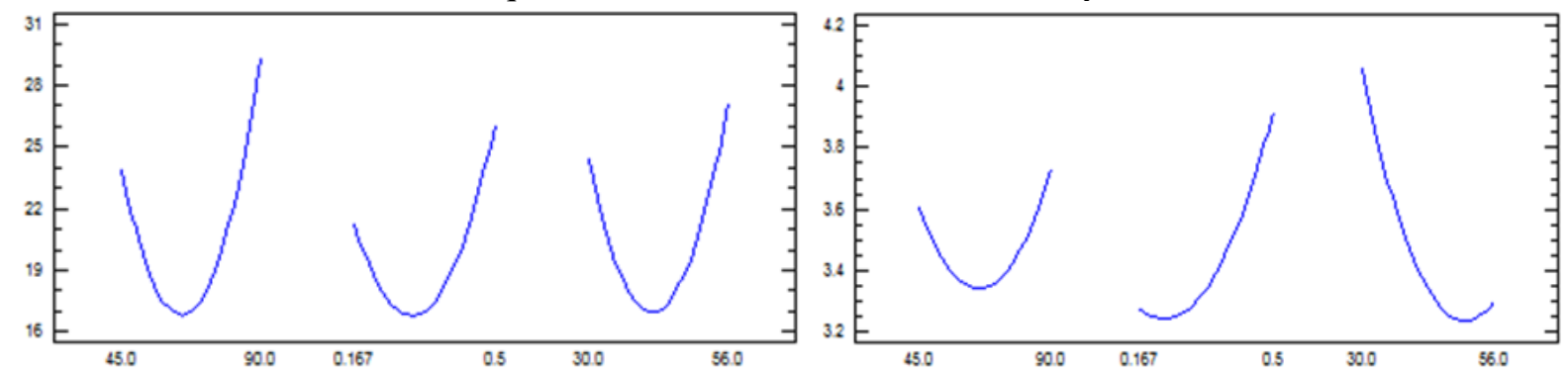

Figure 3. The influence of the effects factors of ratio on the exhaustion of natural color solution on silk fabric and color intensity 


\subsubsection{Optimal conditions for the extracting Diospyros Mollis fruits in acetone}

From the regression function were obtained, carried out the optimal of extracting condition according to the method of surface response by Statgraphics software. The results of optimum extract conditions follows as the extracting temperature at $40{ }^{\circ} \mathrm{C}$, the extracting time 60 minutes and the extracting ratio of Diospyros Mollis fruits/ solvents is $1 / 5$, the ratio of natural colour aqueous on silk fabric is 68.31 and color intensity on fabric is 3.72 .

\subsection{The results of analysis}
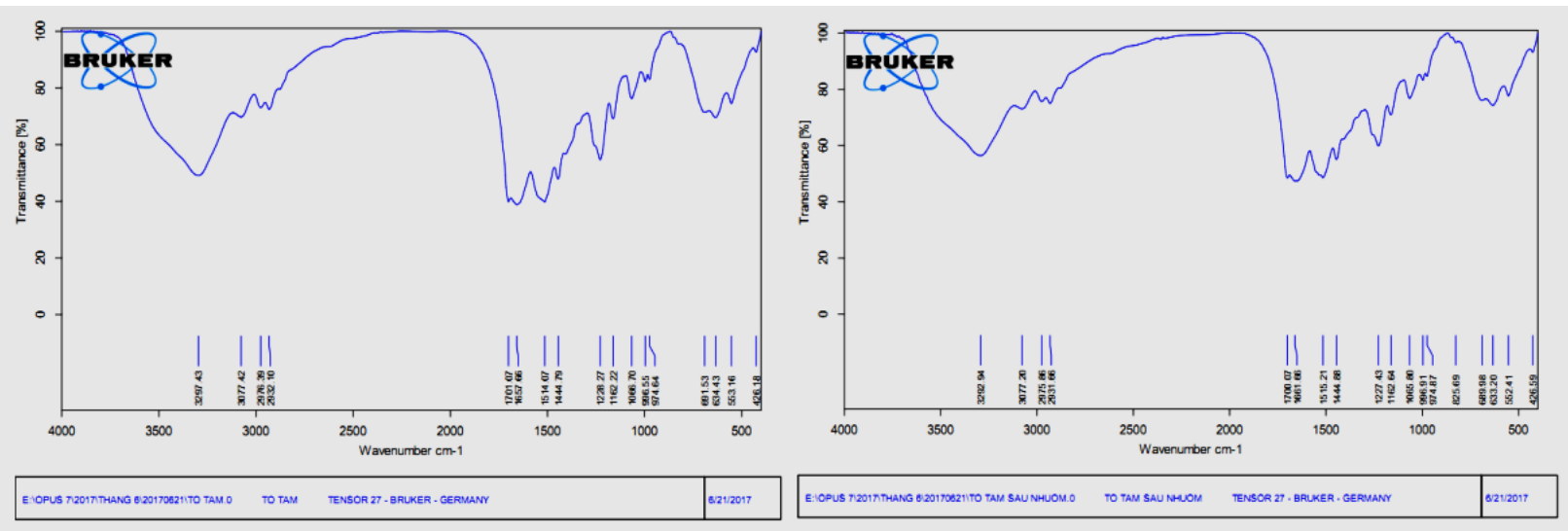

Figure 4. FT-IR of silk before and after dyeing by the solution of Diospyros Mollis fruits

The result of FT-IR of silk before and after dyeing by the solution of Diospyros Mollis fruits in Figure 4 shows composition of silk are acid amine appear at peak N-H 1600-1550 $\mathrm{cm}^{-1}, \mathrm{~N}-\mathrm{H} 1950-1000 \mathrm{~cm}^{-1}, \mathrm{C}-\mathrm{O}$ $1725-1700 \mathrm{~cm}^{-1}, \mathrm{C}-\mathrm{H} 3200-2800 \mathrm{~cm}^{-1}$, O-H $3300-2500 \mathrm{~cm}^{-1}$. On silk after dyeing appear peak of $-\mathrm{OH}$, $\mathrm{C}=\mathrm{O}, \mathrm{C}=\mathrm{C}, \mathrm{C}-\mathrm{N} \ldots$ shows the appearance of absorption spectrum carboxylic acid at $-\mathrm{OH} 3297.43 \mathrm{~cm}^{-1}$.

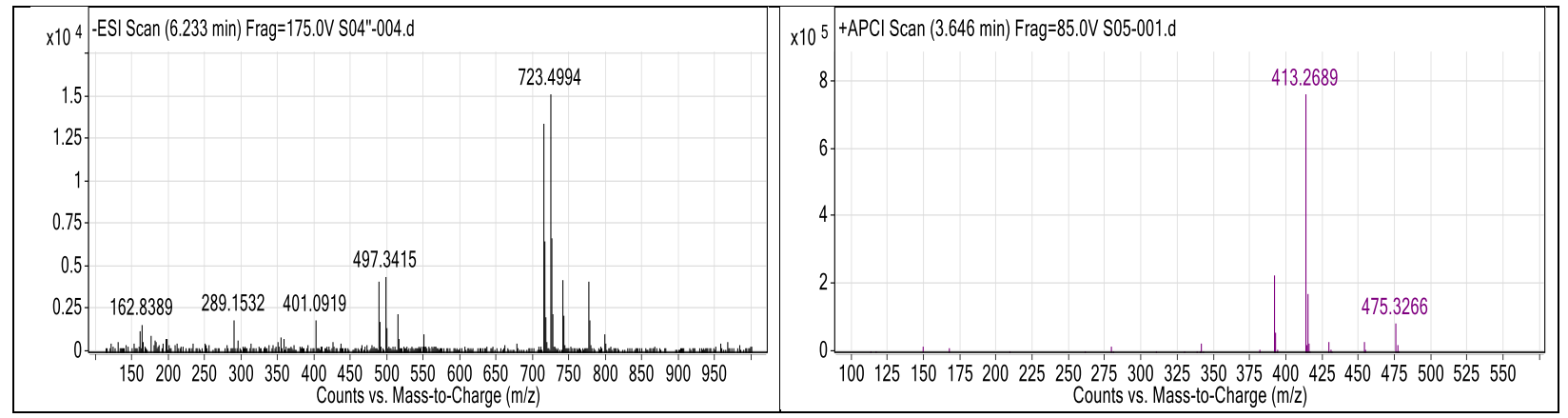

Figure 5. LC-MS of the solution of Diospyros Mollis fruits before and after dyeing for silk

The result of LC-MS in Figure 5 shows the appearance of a lot of components in the aqueous of natural color from Diospyros Mollis fruits such as hydrolysis tannin (pyrogallol $(\mathrm{M}=126)$, condensate tannin (Flavan-3,4-diol (Leucoanthocyanidin-M=242); flavan-3-ols(-)-epicatechin and (+)-catechin $(\mathrm{M}=290)$. Besides, Diospyrol $(\mathrm{M}=346)$; special, in the aqueous of natural color from Diospyros Mollis fruits has also $\beta$-Sitosterol (M=414).

The result of SEM in Figure 6 shows the spectrum LC-MS of the solution of natural color after-dyeing is no existence of these compounds anymore. This proves that the elements of natural color fixed on silk fabrics makes surface structure of silk fabrics changes. Moreover, silk fabric before and after dyeing have different in that the structure of the surface of the dyed fabric appears the film covering the surface of the yarn, on the surface of silk fabric before is none. 

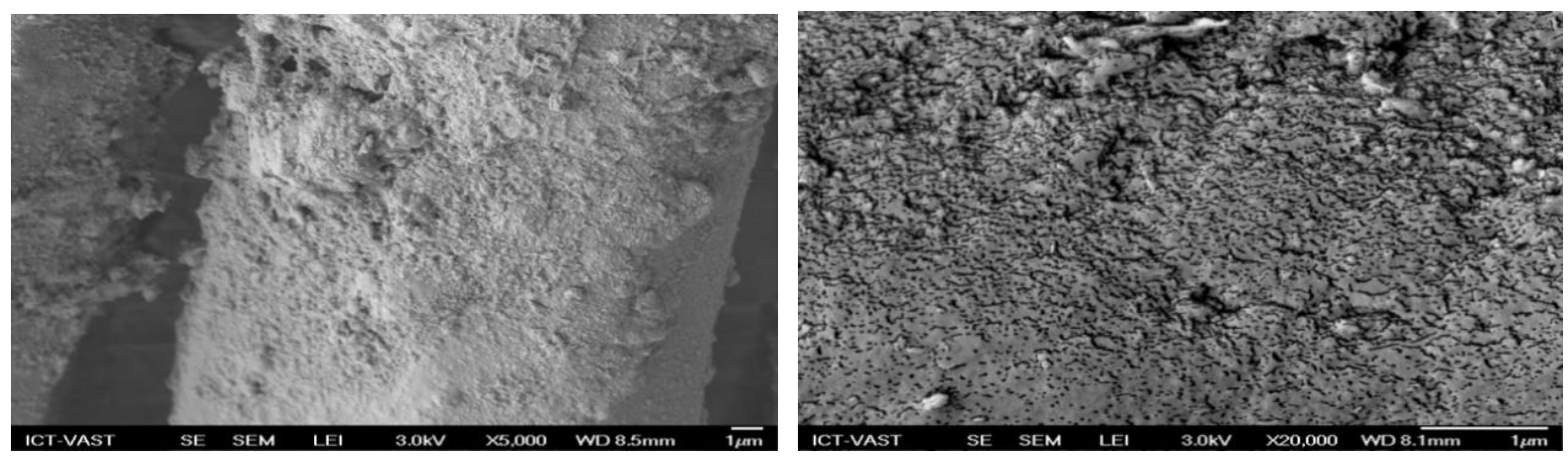

Figure 6. SEM of silk before and after dyeing by the solution of Diospyros Mollis fruits

\section{CONCLUSIONS}

The natural color of Diospyros Mollis fruits are extracted by diethyl ether, acetone, ethanol and distilled water. The results shows the extracting natural color from Diospyros Mollis fruits in acetone solvent can be dyed the silk fabric with high color strength and fastness are obtained level 4-5. The results allow hope a dyeing natural colors technology were produced in industrial model, an utilizing waste material, solve environmental problems towards green technology and sustainable development.

\section{REFERENCES}

[1]. Hoang Thi Linh, Tran Dang Phong, Nguyen Van Thong...- Technique of dyeing, printing and finishing textiles, Science and Technology Publishing House, (2004), 481.

[2]. Nguyen Canh, Nguyen Dinh Soa, Empirical optimization of chemical and chemical engineering, University of Technology Ho Chi Minh City Publishing House (1994).

[3]. Tran Kim Quy, "Engineering of colorants", Ho Chi Minh City Publishing House (1987).

[4]. J. Loder, S. Mongolsuk, A. Robertson and W. Whalley, "430. Diospyrol, a constituent of Diospyros mollis", Journal of the Chemical Society (Resumed), p. 2233, 1957.

[5]. K. Yoshihira, M. Tezuka, P. Kanchanapee and S. Natori, "Naphthoquinone Derivatives from the Ebenaceae. I. Diospyrol and the Related Naphthoquinones from Diospyros mollis GRIFF.", Chemical \& Pharmaceutical Bulletin, vol. 19, no. 11, p. 2271-2277, 1971.

[6]. Phạm Thị Hồng Phượng, Hoàng Thị Lĩnh, Trần Trung Kiên, Lê Võ Sơn Quân (2013) Tối uu hóa quá trình nhuộm vái tơ tằm bằng dịch chiết tù quả mặc nưa, Tạp chí Khoa học và Công nghệ, 51 (5B), pp: 248-252.

[7]. Hong Phuong Pham Thi, Linh Hoang Thi, Trung Kien Tran, Bich Phuong Nguyen Thi (2015), Optimization of temperature, time and extract ratio of the aqueous extract process from mangosteen peel for dyeing silk, Hội nghị Quốc tế ĐHBK TP.HCM, The 2nd International Conference on Chemical Engineering, Food and Bio Technology (ICCFB2015).

[8]. Hong Phuong Pham Thi, Linh Hoang Thi, Trung Kien Tran, Kim Thao Le (2015) Research on the influence of the extracted temperature and time from the fruice of diospyros mollis on the colour strength and the fastness properties of cotton, silk and polyamide, Hội nghị Quốc tế ĐHBK Hà Nội, Chemical Innovation for a Progress in ASEAN Industry and Society (RCChE2015). 


\section{TRÍCH LY MÀU TỬ NHIÊN TÙ̉ QUẢ MẶC NƯA (DIOSPYROS MOLLIS GRIFF.) BẦNG NHIỀU DUNG MÔI KHÁC NHAU VÀ ÚNG DỤNG NHUỘM VẢI TƠ TẰM}

Tóm tắt. Cây mặc nưa là một cây mọc hoang, quả được sử dụng để nhuộm màu đen, sản phẩm nổi tiếng được nhuộm từ quả mặc nưa là Lãnh Mỹ $\mathrm{A}$ ở Tân Châu, An Giang. Trong nghiên cứu này, tác giả sử dụng bốn dung môi là nước, ethanol, acetone và diethyl ether để trích ly màu tự nhiên từ quả mặc nưa và sau đó đem nhuộm trên vải tơ tằm. Kết quả, màu tự nhiên trích bằng dung môi acetone khi nhuộm lên vải tơ tằm cho cường độ màu 3.72 tốt nhất trong các dung môi khảo sát. Vải tơ tằm sau nhuộm đạt các chỉ tiêu về độ bền màu cấp $4-5$, độ bền cơ lý cao và đảm bảo các tính chất sinh thái.

Từ khóa. Quả mặc nưa, tơ tằm, nhuộm tự nhiên

Ngày nhận bài: 19/03/2020

Ngày chấp nhận đăng: 04/05/2020 